\title{
Status of shallow wells along major rivers of the Kathmandu Valley, Central Nepal
}

\author{
*Ramita Bajracharya1, Naresh Kazi Tamrakar ${ }^{1}$, Manish Shrestha ${ }^{2}$, and Bimal Bohara ${ }^{2}$ \\ ${ }^{1}$ Central Department of Geology, Tribhuvan University, Kirtipur, Kathmandu, Nepal \\ ${ }^{2}$ Shivan Cement Industries, Hetauda, Nepal \\ *Corresponding author: bajrarami@gmail.com
}

\begin{abstract}
Groundwater is one of the important natural resources to which people of the Kathmandu Valley rely on for their daily purpose. The rate of extraction of groundwater from shallow as well as deep aquifers has increased in the river corridor with the increased urbanization towards the major river corridors in the valley. Wells located within $100 \mathrm{~m}$ from the rivers of the Kathmandu Valley were focused in the present study. Altogether 237 wells were recorded from the Bagmati, Manahara and the Bishnumati River corridors of the northern Kathmandu basin, and the Dhobi, Hanumante, Godavari, Kodku, Nakhu and the Balkhu Khola corridors of the southern Kathmandu basin. This research was based on field measurements of well dimension (well diameter, well depth and water level depth) and physical parameters (electrical conductivity, dissolve oxygen, $\mathrm{pH}$ and temperature) in April and August of year 2017. The lowest water level was measured in the Nakhu Khola and the highest was measured in the Dhobi Khola in dry season. Average EC ranged between 614.2 $\mu \mathrm{S} / \mathrm{cm}$ and $1123.9 \mu \mathrm{S} / \mathrm{cm}$ in dry season, and between $613.0 \mu \mathrm{S} / \mathrm{cm}$ and $916.1 \mu \mathrm{S} / \mathrm{cm}$ in wet season. DO also varied from $1.46 \mathrm{mg} / \mathrm{L}$ to $2.46 \mathrm{mg} / \mathrm{L}$ in dry season and increased to $1.67-2.53 \mathrm{mg} / \mathrm{L}$ in wet season. The lower DO and higher EC in the Balkhu Khola corridor indicates the most contaminated wells in the Kathmandu Valley. Average values of $\mathrm{pH}$ and temperature increased in wet season compared to dry season. Average high values of EC and low values of DO were recorded within $30 \mathrm{~m}$ distance from the rivers, and EC increased and DO decreased as the distance from river channel increased.
\end{abstract}

Keywords: Water quality, Well dimension, Dissolved oxygen, Kathmandu Valley, River corridor, Bagmati River

Paper Received: 22 Mar 2018

Paper Accepted: 21 May 2018

\section{INTRODUCTION}

Groundwater is one of the important natural resources to which majority of the world's population depend on for their daily lives. In Nepal, it is the major source of drinking water in both urban and rural areas. In the Kathmandu valley, the government authorized institution; Kathmandu Upatyaka Khanepani Limited (KUKL) could not fulfill the total amount of water (around 370 million/day) needed. The demand has been largely contributed from groundwater source (Panday et al. 2012). The dependency towards the use of groundwater in the valley has been increasing with the growth of population and industrial activity (Panday et al. 2010). The rapid growth of urbanization for last one decade has also increased settlements along the river corridors. These increased settlements contribute to contaminate the river and surface water through solid waste disposal, industrial waste and agriculture waste which have further increased the dependency toward the groundwater use. The overexploitation of the groundwater and change of land use by clearing vegetation and forming impervious surfaces have decreased groundwater table and minimized groundwater recharge (Panday et al. 2010; Gautam and Prajapati, 2014).

Rapid urbanization along the river corridors exploits groundwater from both shallow and deep aquifers. Housing, industries and large colonies mostly exploit groundwater from deep aquifer whereas individual houses fulfill their water demand by digging dug wells and shallow tube wells. Consequently, the shallow aquifer has higher possibility of being contaminated by anthropogenic activities which were also reported in previous researches that the shallow aquifer has higher concentration of nitrate, EC, iron, chloride and turbidity exceeding Nepal standard (Warner et al., 2008; Prasai et al., 2010; Diwakar et al., 2010; Pant, 2011). But there are very few researches, which were conducted based on shallow aquifer extraction rate, shallow well inventory and water level as well as fluctuations of major physio-chemical parameters (Shrestha and Shah, 2014). Many researches were conducted including combined groundwater quality of shallow and deep aquifer; stone spots and spring water (Khadka, 1993; Pathak and Hiratsuka, 2010; Ghimire et al., 2013). As shallow aquifers near the rivers are often the most exploited and are the ones being possibly contaminated by the polluted river water and riverbank areas, the present study tried to include most of dug wells which are located within $100 \mathrm{~m}$ spans from both right and left banks of the corridors of major rivers of the Kathmandu Valley. This study was totally focused on in situ field measurement data such as well dimension ( well diameter, well depth and water level depth) and some parameters like electrical conductivity, dissolved oxygen, $\mathrm{pH}$ and temperature. The aims of this study were to find out (i) status of dug wells based on well dimension and physical parameter, 
(ii) seasonal variation in water level depth and physical parameter, and (iii) relation between proximity from rivers and physical parameters.

\section{GEOLOGICAL SETTING}

The Kathmandu Valley is located between latitudes $27^{\circ} 32^{\prime} 13^{\prime \prime}$ and $27^{\circ} 49^{\prime} 10^{\prime \prime}$ north and longitudes $85^{\circ} 11^{\prime} 31^{\prime \prime}$ and $85^{\circ} 31^{\prime} 38^{\prime \prime}$ east covering area about $650 \mathrm{sq}$. $\mathrm{km}$. The bowlshaped valley extends for $30 \mathrm{~km}$ towards E-W and $25 \mathrm{~km}$ towards N-S. The valley has average elevation of $1350 \mathrm{~m}$ and enclosed by peaks of the Shivapuri, Chandragiri and the Phulchauki ranges from the north, the south, and the west, respectively. The Bagmati River is the only one outlet drainage of the valley, and has many tributaries such as Bishnumati River, Dhobi Khola, Manahara River, Hanumante River, Godawari River, Kodku River, Nakhu River and Balkhu River.

The surrounding mountain ranges of the valley are composed of sedimentary and metamorphic rocks with gneiss and migmatites (Stöcklin, 1980) whereas the valley fill consists of Plio-Pleistocene fluvial, fluvial lacustrine and fluvio-deltaic sediments (Yoshida and Igarashi, 1984; Shrestha et al., 1998; Sakai et al., 2008). The lacustrine and fluvial deposits of the valley contain peat, clay, carbonaceous clay, sand, gravel and boulders. They lie unconformably on the rocks of the Phulchauki Group and the Bhimphedi Group. The basin-fill sediments were divided into different units (Table 1).

Within the Kathmandu Valley, the present study area was located on the major river corridors which include basin fill sediments of the Lower Terrace Deposits, Alluvial Fan or Debris Flow Deposit, Lukundol Formation, Gokarna Formation, Thimi Formation and the Patan Formation (Fig. 1). Based on observed lithological data of different location, the Kathmandu Valley was divided into three groundwater districts as northern, central and southern groundwater districts (JICA, 1990). As per sub-surface layer data, the Northern Groundwater District is considered as recharge belt of the Kathmandu valley.

\section{METHODOLOGY}

Dug wells which were located within $100 \mathrm{~m}$ from the corridors of the major 9 tributaries; the Bishnumati, Manahara and the Bagmati Rivers, and the Dhobi, Hanumante, Godavari, Kodku, Nakhu and the Balkhu Kholas in the Kathmandu Valley were selected for this study. This study tried to include all those dug wells which were located within $100 \mathrm{~m}$ from river corridor but some was not possible due to absence of owner at the time of survey. GPS location, well dimension (well depth, well diameter and water level depth) and some parameters such as electrical conductivity (EC), dissolved oxygen (DO), $\mathrm{pH}$ and water temperature was measured in situ at each well location.

Well depth, well diameter and water level depth of each well were measured by using measuring tape and water depth logger for water level depth. The total well depth was also noted in the field through owner information or from direct measurement. And parameters such as EC, DO, $\mathrm{pH}$ and water temperature were measured by using portable measuring devices such as DO-meter (Mettler Toledo SG3-ELK) and pH/EC meter

Table 1: Stratigratigraphic units of valley-fill sediments (Yoshida and Igarashi, 1984 and Sakai et al., 2008)

\begin{tabular}{|c|c|c|}
\hline Stratigraphic unit & Geological Age & Composition \\
\hline River Flood Plain & Holocene & Sand, silt and clay. \\
\hline Lower Terrace deposits & Holocene & Micaceous sand, pebbles and gravel \\
\hline Patan Formation & Pleistocene & Laminated arkosic sand, silt, clay and peat layers. \\
\hline Kalimati Formation & Pleistocene & $\begin{array}{l}\text { Black clay or silt (kalimati) beds with thin beds of } \\
\text { very fine sands. }\end{array}$ \\
\hline Thimi Formation & Pleistocene & $\begin{array}{l}\text { Arkosic sand, silt clay, peat and gravel, gravel are } \\
\text { mainly of gneiss and granite. }\end{array}$ \\
\hline Tokha Formation & Pleistocene & $\begin{array}{l}\text { Pale green silty sand and gravel lenses with black } \\
\text { silt and thin diatomite. }\end{array}$ \\
\hline Gokarna Formation & Pleistocene & Laminated arkosic sand, silt clay and peat. \\
\hline Boregaon Terrace deposit & Pleistocene & $\begin{array}{l}\text { Rounded gravel with silt and sand laminated, } \\
\text { gravel composed of limestone, metasandstone. }\end{array}$ \\
\hline Chapagaon Terrace Deposit & Pleistocene & $\begin{array}{l}\text { Subrounded cobbles and pebbles of metasandstone, } \\
\text { limestone and phyllite }\end{array}$ \\
\hline Pyangaon Terrace deposit & Pleistocene & $\begin{array}{l}\text { Rounded to sub rounded cobbles and pebbles of } \\
\text { meta-sandstone, limestone and phyllite. }\end{array}$ \\
\hline Dharmasthali Formation & Plio-Pleistocene & Silt beds with intercalation of gravel and sand. \\
\hline Lukundol Formation & Plio-Pleistocene & $\begin{array}{l}\text { Weakly consolidated clay, silt and beds with lignite } \\
\text { layers. Subdivided into Basal Conglomerate, } \\
\text { lignite and laminated silt members }\end{array}$ \\
\hline
\end{tabular}


(Mettler Toledo Duo). All these data were measured at each well site after removing some water by using rope and plastic bucket.

The well number was given based on the name of river such as BMW for Bishnumati corridor well; DW for Dhobi; BW for Bagmati; MW for Manahara; HW for Hanumante; GW for Godavari; KW for Kodku; NW for Nakhhu and BAW for Balkhu corridor wells. Measurement of well dimension and physio-chemical parameters were carried out in dry (April 2017) and wet (August 2017) seasons.

\section{RESULTS AND DISCUSSIONS}

The numbers of wells recorded for different river corridor was different and was given in Table 2. The total numbers of recorded wells from nine river corridors were 237 among which 117 dug wells were from northern rivers (Bishnumati, Dhobi, Bagmati and Manahara) and 120 were from southern rivers (Hanumante, Godavari, Kodku, Nakhhu and Balkhu) of the valley (Fig. 1).
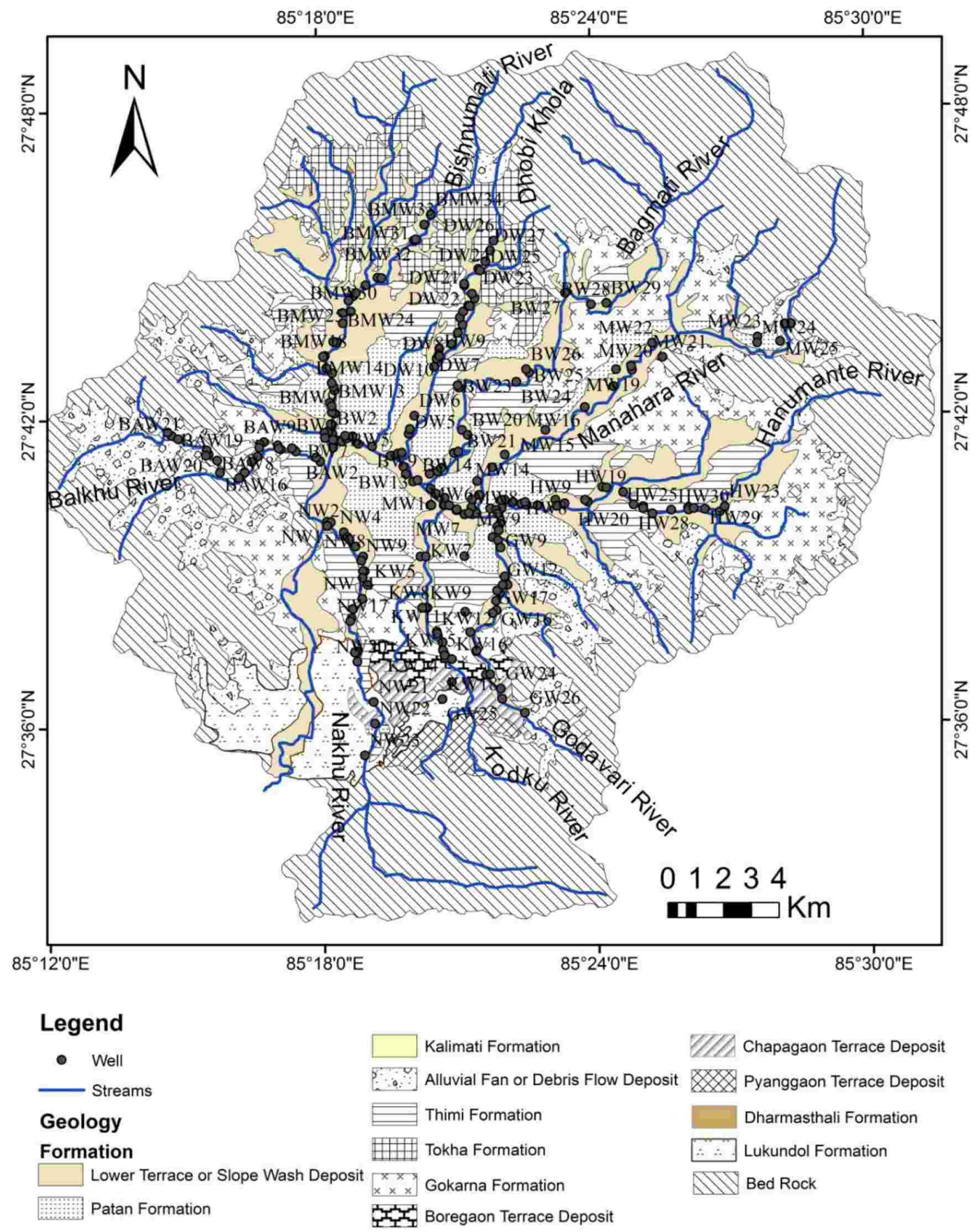

Fig. 1: Well location on geological map of the Kathmandu valley (Compilation of Yoshida \& Igarashi, 1984; Shrestha et al., 1998; Sakai et al., 2008 and Dhital, 2015) 
Table 2: Value ranges of well dimension and elevation

\begin{tabular}{lllllll}
\hline $\begin{array}{l}\text { Name of } \\
\text { tributaries }\end{array}$ & $\begin{array}{l}\text { No. of } \\
\text { Wells }\end{array}$ & & Elevation $(\mathbf{m})$ & $\begin{array}{l}\text { Well Diameter } \\
(\mathbf{m})\end{array}$ & $\begin{array}{l}\text { Well Depth } \\
(\mathbf{m})\end{array}$ & \multicolumn{2}{l}{ Water level Depth (m) } \\
\cline { 6 - 7 } & & & & & Dry & Wet \\
\hline Bishnumati River & 34 & $1280-1309$ & $0.8-1.2$ & $2.2-7.1$ & $0.9-6.8$ & $0.4-4.2$ \\
Dhobi Khola & 27 & $1277-1329$ & $0.9-1.2$ & $2.3-12.2$ & $1.1-11.8$ & $0.1-3.1$ \\
Bagmati River & 29 & $1267-1329$ & $0.8-1.6$ & $1.9-8.45$ & $0.9-5.8$ & $0.6-5.7$ \\
Manahara River & 28 & $1276-1390$ & $0.8-1.2$ & $1.15-7.65$ & $0.6-5.7$ & $0.1-5.0$ \\
Hanumante Khola & 30 & $1280-1315$ & $0.8-1.2$ & $1.5-15.7$ & $1.1-6.3$ & $0.1-5.6$ \\
Godavari Khola & 26 & $1293-1429$ & $0.9-1.3$ & $1.5-10.4$ & $0.45-8.3$ & $0.1-4.5$ \\
Kodku Khola & 18 & $1288-1430$ & $0.9-2.3$ & $2.3-9.9$ & $0.4-8.3$ & $0.1-6.4$ \\
Nakhu Khola & 23 & $1263-1400$ & $0.6-1.2$ & $1.4-14.4$ & $0.2-3.8$ & $0.1-2.6$ \\
Balkhu Khola & 23 & $1267-1345$ & $0.8-1.2$ & $2.8-10.8$ & $1.3-8.1$ & $0.1-3.0$ \\
\hline
\end{tabular}

\section{Well dimension and water level depth}

The well diameter, well total depth and water level depth were measured in each well. The maximum and minimum ranges for each measurement were presented in Table 2. In all nine rivers, minimum well diameter was ranged from 60 to 90 $\mathrm{cm}$ where as maximum was from 120 to $230 \mathrm{~cm}$. These wells were located at different elevation. The highest elevation was observed at upstream sections of the Godavari Khola, Kodku Khola and the Nakhu Khola (1400 to $1430 \mathrm{~m}$ ) and the lowest was at downstream sections of all tributaries (1263 to $1293 \mathrm{~m}$ ).

The total well depth was very much variable along and among wells of different tributaries. The shallowest well depth was observed at the Manahara River $(1.15 \mathrm{~m})$ whereas the deepest one was noted from the Hanumante Khola (15.7 m). Wells of the Bishnumati River and the Manahara River corridors have the lowest well depth (Fig. 2). In the study area, depths of wells which were located on the Lower Terrace Deposit, Chapagaon Terrace Deposit and Boreaon Terrace Deposit have lower well depth as compared with those wells which were located on the Patan Formation and Thimi Formation. The Terrace Deposits mainly consists of gravels, pebbles, sand whereas Patan and Thimi Formation contain sand, silt, clay and peat layers. This indicates that depth of wells depends on the subsurface lithology of well location.

Water level depth varied from 0.2 to $11.8 \mathrm{~m}$ in dry month. Lower water level was noticed from well near to the Nakhu River and higher depth was from well near to the Dhobi Khola (Fig. 3). Except in few wells, all other wells have lower water level depths (from 0.1 to $6.4 \mathrm{~m}$ ) in wet season as compared to dry season. Comparing well along northern and southern corridors, most of southern wells have lower water level $(0.1-0.3$ $\mathrm{m})$ in wet season. Water level depth was variable for wells located within a single tributary as well as among different tributaries. The lowest level of variation was recorded in the Nakhu Khola (3.6 m) and the highest was obtained in the Dhobi Khola $(10.7 \mathrm{~m})$ in dry season which was changed to $2.5 \mathrm{~m}$ in the Nakhu Khola and $6.3 \mathrm{~m}$ in the Kodku Khola during wet season (Fig. 4 and Table 2).
Comparing among wells distributed in nine different corridors of the northern and the southern regions of the Kathmandu Valley, the Nakhu Khola has the lowest water level depth in the study period (Fig. 3). But comparing water level depth with lithology of well location, it can be found that most of wells which were located on Lower Terrace Deposit have lower water level depth. The wells of northern and southern corridors located on the terrace deposit have different water level depth. Rate of urbanization along river corridors was higher in northern river such as the Bishnumati, Dhobi and the Bagmati Rivers as compared to the southern rivers, Nakhhu, Kodku and Godavari. Increased urbanization can also increased withdraw of water from wells which can increase water level depth and thus withdraw rate may be one possible reason for lower water level depth in southern river corridor wells.

\section{Physical parameters}

Some parameters of water such as temperature, $\mathrm{pH}$, electrical conductivity (EC) and dissolved oxygen (DO) were measured in each well in dry and wet season. Minimum, maximum and average data of these parameters for each nine rivers are presented in Table 3.

\section{Temperature}

Groundwater temperature is one of important parameters as it can affect physical, chemical and biological activities. Increase in temperature can decrease solubility of gases such as $\mathrm{O}_{2}, \mathrm{CO}_{2}$ and $\mathrm{N}_{2}$ (Yilmaz and Koc, 2014). Higher temperature also increases taste, odour, colour and corrosion problem due to growth of microorganism (UNICEF, 2008). Increase in temperature also decreases the amount of dissolved oxygen, accelerates nitrification and oxidation of ammonia to nitrates and create oxygen deficient water environment (Ngabirano et al., 2016). Groundwater average temperature in dry season varied from 17.6 to $19.8^{\circ} \mathrm{C}$ in which the lowest was measured from wells near to the Kodku Khola whereas the highest one was measured from the wells near to the Dhobi Khola. Variation in temperature among nine river corridor wells may be due to 


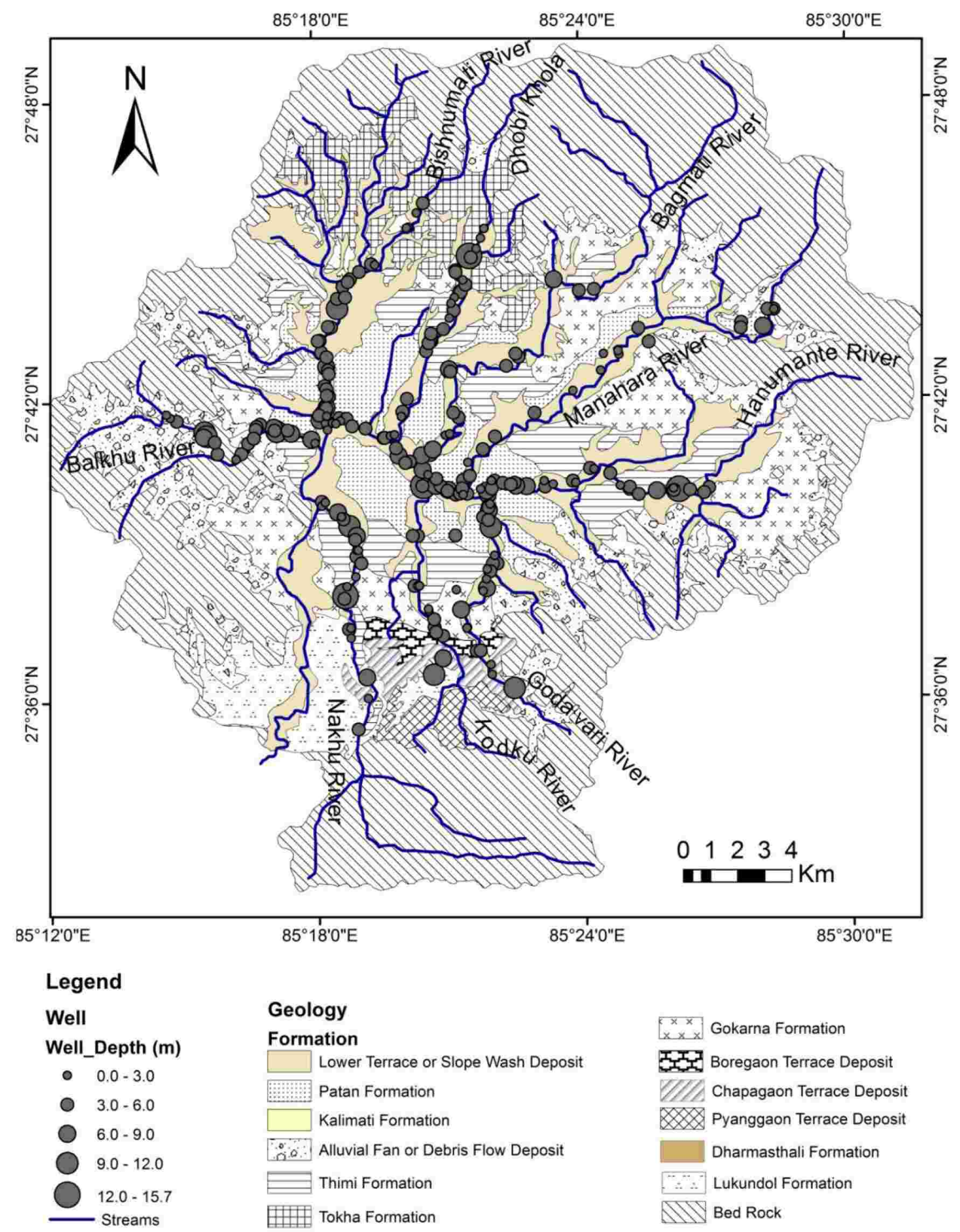

Fig. 2: Well depth variation on wells

change in depth of water, different timing of sample collection and mixing whether cold or warm from the surrounding rocks and soils in the plumes (Ngabirano et al., 2016). Seasonal variation was also occurred in wet season with value ranging from 22.59 to $23.66^{\circ} \mathrm{C}$.

\section{pH}

The $\mathrm{pH}$ indicates hydrogen concentration in the water which is affected by dissolved gases and salts. Average value of $\mathrm{pH}$ ranged from 6.69 to 7.33 in dry season but very low $\mathrm{pH}$ was measured in some wells near to the Hanumante, Manahara and the Kodku tributaries as 5.67, 5.96 and 6.16, respectively which were below permissible limit of NWQDS (WHO Nepal, 2005). A water sample with less than $7 \mathrm{pH}$ is considered as acidic and can corrosive metal such as copper, zinc, lead from pipes causing increasing level of toxic metal in water (Aytekin and Bayraktaroglu, 2014). Higher $\mathrm{pH}$ was noted in well near to the Bishnumati River (8.5) which is disadvantage in order to treat with chlorine (Oyem et al., 2014). Except in few wells, $\mathrm{pH}$ has changed to slightly basic in the wet season with average value ranging from 7.19 to 7.41 (Table 3 and Fig. 5) indicating wet seasons has greater $\mathrm{pH}$ as compared to dry season (Ramamohan and Sudhakar, 2014; Zhou et al., 2015).

\section{Electrical Conductivity (EC)}

Electrical conductivity (EC) is the measure of ionic component dissolved in the water and gives an indication of 


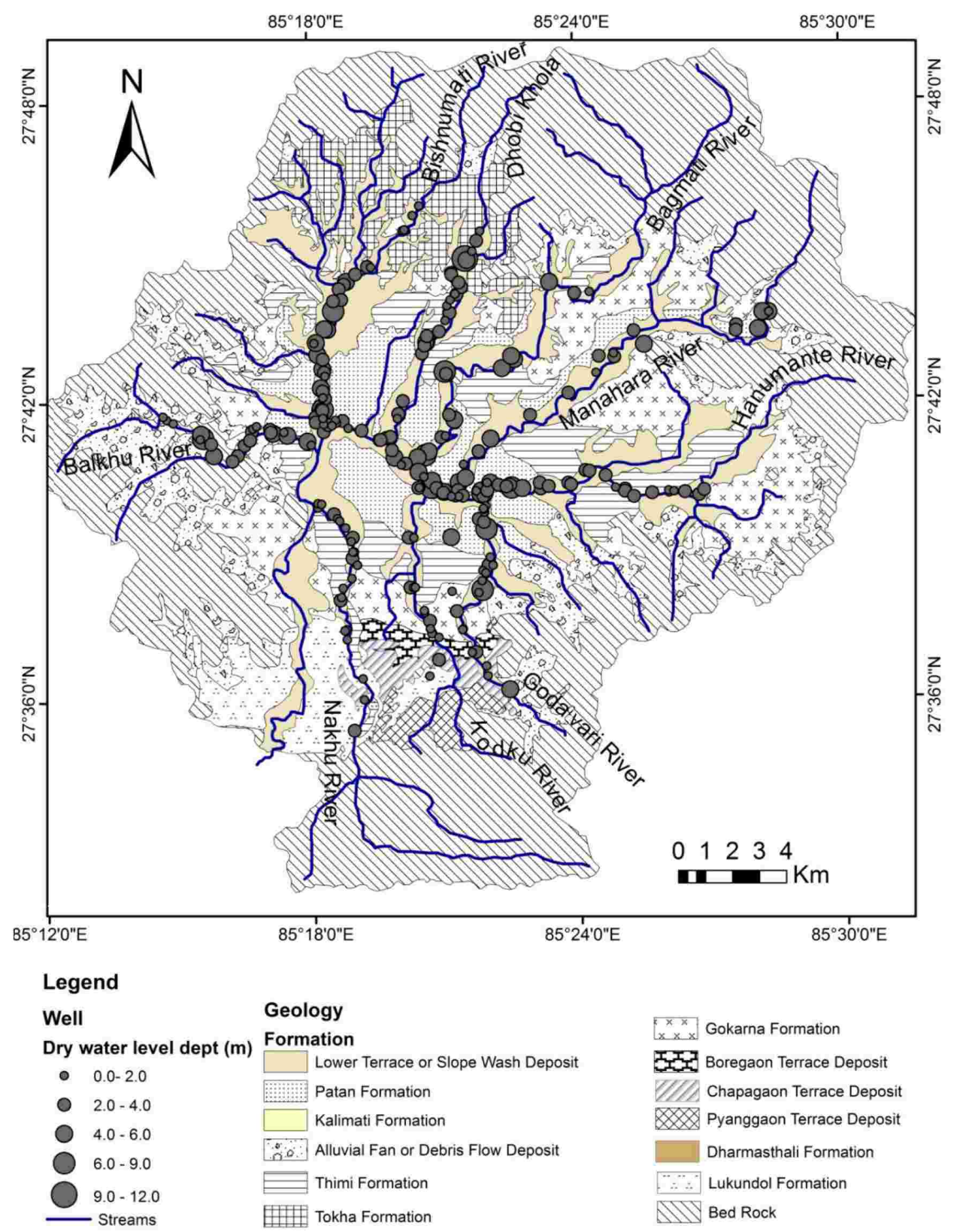

Fig. 3: Water level depth variation in dry season (April 2017)

the amount of total dissolved substitution in water (Yilmaz and Koc, 2014). EC was spatially and temporally very much variable (Table 3). Average EC value ranged from 614.2 to $1123.9 \mu \mathrm{S} / \mathrm{cm}$ in dry season and then decreased to 613.0 and $916.1 \mu \mathrm{S} / \mathrm{cm}$ in wet season. In both seasons, the highest value was observed in the wells of the Balkhu Khola corridor and the lowest was in the wells of the Nakhu Khola corridor (Fig. 6). Except in few wells, all other wells have lower EC in wet as compared to dry season. Evaporation rate generally is higher in dry season increasing ions concentration and hence increase EC but in the case of wet season there is dilution of ions due to rainwater infiltration and can increase water volumes resulting in a decrease in EC (Ngabirano et al., 2016).
In each river, wells located in the upstream segments of the tributaries have the lowest EC value as compared with the wells of the downstream segments indicating higher values towards downstream urbanized area (Fig. 7). The higher EC indicates higher concentration of dissolved ions. These ionic substances were available to groundwater by infiltration of solid wastes, industrial wastes, agricultural wastes, leakage of safety tank and sewer pipes (Pant, 2011).

When the EC is compared among the wells located in different corridors, the samples from the downstream of the Balkhu Khola corridor has the highest EC but the samples from the Nakhu Khola and the Dhobi Khola corridors have the least values both in wet and dry seasons (Table 3). Wells of the Nakhu and the Dhobi Khola corridors only were within permissible 


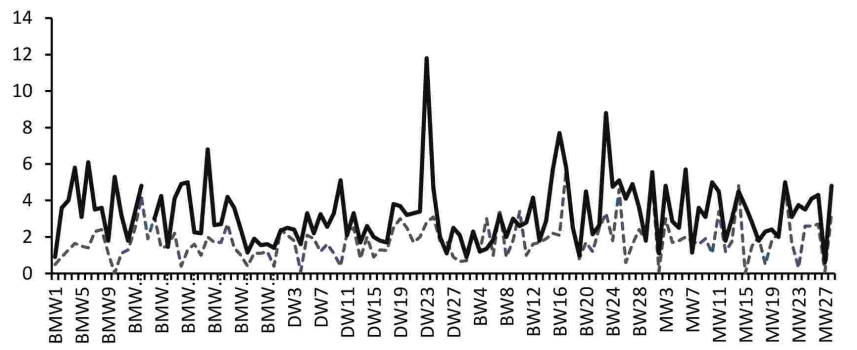

(a)

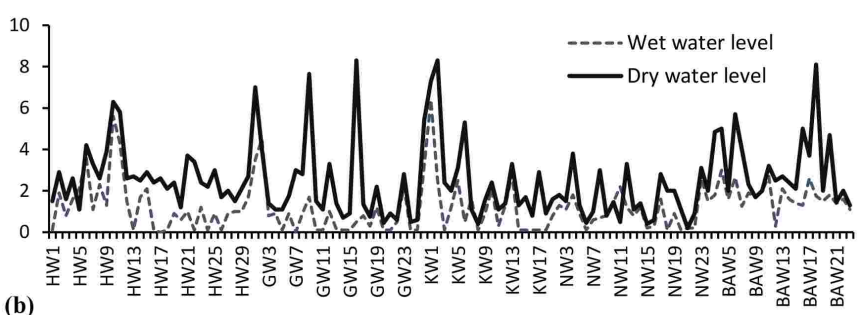

Fig. 4: Water level depth in wet and dry seasons at (a) Northern tributaries (Bishnumati, BMW; Dhobi, DW; Bagmati, BW and Manahara, MW), and (b) Southern tributaries (Hanumante, HW; Godavari, GW; Kodku, KW; Nakhu, NW andBalkhu, BAW) rivers

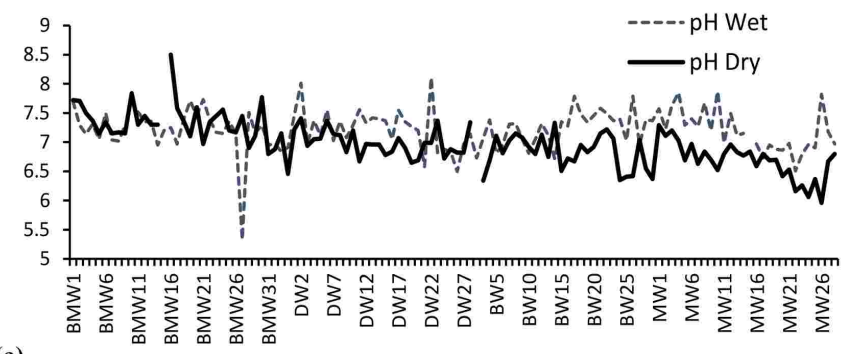

(a)

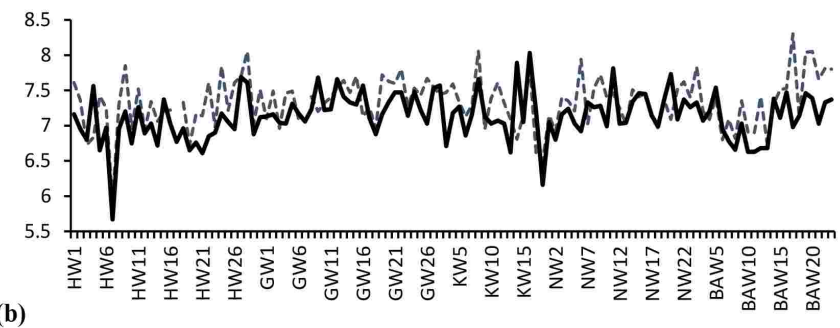

Fig. 5: pH variation in wells of a) northern and b) southern river corridors in wet and dry seasons

Table 3: Maximum, minimum and average value of physical parameters of wells

\begin{tabular}{|c|c|c|c|c|c|c|c|c|c|}
\hline \multicolumn{2}{|c|}{ River corridor Name } & \multicolumn{2}{|l|}{$\mathbf{E C}$} & \multicolumn{2}{|l|}{ pH } & \multicolumn{2}{|l|}{ DO } & \multicolumn{2}{|c|}{ Temperature } \\
\hline & & Dry & Wet & Dry & Wet & Dry & Wet & Dry & Wet \\
\hline \multirow[t]{3}{*}{ Bishnumati River } & Min & 260 & 334 & 6.46 & 5.33 & 0.26 & 0.33 & 16.2 & 21.6 \\
\hline & $\operatorname{Max}$ & 2150 & 2090 & 8.5 & 7.73 & 5.93 & 6.34 & 21.6 & 25.8 \\
\hline & Average & 1014 & 851.73 & 7.33 & 7.19 & 2.39 & 2.18 & 18.74 & 23.4 \\
\hline \multirow[t]{3}{*}{ Dhobi Khola } & Min & 231 & 162.5 & 6.65 & 6.5 & 0.37 & 0.48 & 18.4 & 21.8 \\
\hline & Max & 1481 & 1199 & 7.41 & 8.11 & 6.06 & 4.88 & 21.2 & 24.8 \\
\hline & Average & 745 & 656.91 & 6.98 & 7.24 & 2.46 & 2.18 & 19.83 & 23.29 \\
\hline \multirow[t]{3}{*}{ Bagmati River } & Min & 149.6 & 121.7 & 6.34 & 6.71 & 0.19 & 0.26 & 17.1 & 20.7 \\
\hline & Max & 2280 & 1949 & 7.34 & 7.79 & 4.8 & 8.55 & 23.4 & 25.8 \\
\hline & Average & 963 & 872.16 & 6.84 & 7.24 & 1.48 & 2.16 & 19.69 & 23.34 \\
\hline \multirow[t]{3}{*}{ Manahara River } & Min & 119.8 & 148.5 & 5.96 & 6.51 & 0.37 & 0.52 & 16.9 & 20.2 \\
\hline & Max & 2070 & 1922 & 7.29 & 7.87 & 5.43 & 6.36 & 20.9 & 27.6 \\
\hline & Average & 692 & 666.28 & 6.69 & 7.19 & 2.31 & 2.27 & 18.90 & 23.60 \\
\hline \multirow[t]{3}{*}{ Hanumante Khola } & Min & 549 & 228 & 5.67 & 5.92 & 0.54 & 0.55 & 18.1 & 20.7 \\
\hline & $\operatorname{Max}$ & 1546 & 2158 & 7.69 & 8.05 & 4.67 & 4.88 & 20.7 & 24.7 \\
\hline & Average & 892 & 852.90 & 6.96 & 7.26 & 1.72 & 2.53 & 19.37 & 22.82 \\
\hline \multirow[t]{3}{*}{ Godavari Khola } & Min & 303 & 299 & 6.88 & 6.96 & 0.5 & 0.77 & 15.3 & 19.6 \\
\hline & Max & 2090 & 1575 & 7.68 & 7.8 & 5.78 & 5.21 & 24 & 25.6 \\
\hline & Average & 707 & 622.40 & 7.26 & 7.41 & 2.26 & 1.93 & 18.07 & 23.38 \\
\hline \multirow[t]{3}{*}{ Kodku Khola } & Min & 230 & 183 & 6.16 & 6.51 & 0.09 & 0.42 & 15.5 & 20 \\
\hline & Max & 1840 & 1568 & 8.03 & 8.06 & 5.45 & 5.04 & 22 & 24.9 \\
\hline & Average & 710 & 749.44 & 7.18 & 7.29 & 1.67 & 1.94 & 17.67 & 22.59 \\
\hline \multirow[t]{3}{*}{ Nakhu Khola } & Min & 242 & 244 & 6.8 & 6.92 & 0.5 & 0.19 & 18.2 & 21.6 \\
\hline & Max & 1131 & 1540 & 7.81 & 7.94 & 5.7 & 5.05 & 20.9 & 25.1 \\
\hline & Average & 614 & 613.04 & 7.22 & 7.34 & 2.15 & 2.11 & 19.51 & 23.42 \\
\hline \multirow[t]{3}{*}{ Balkhu Khola } & Min & 553 & 385 & 6.63 & 6.73 & 0.11 & 0.33 & 18.4 & 21.7 \\
\hline & Max & 2860 & 3030 & 7.54 & 8.3 & 3.46 & 3.64 & 20.6 & 25.2 \\
\hline & Average & 1124 & 916.18 & 7.08 & 7.39 & 1.46 & 1.67 & 19.46 & 23.66 \\
\hline
\end{tabular}




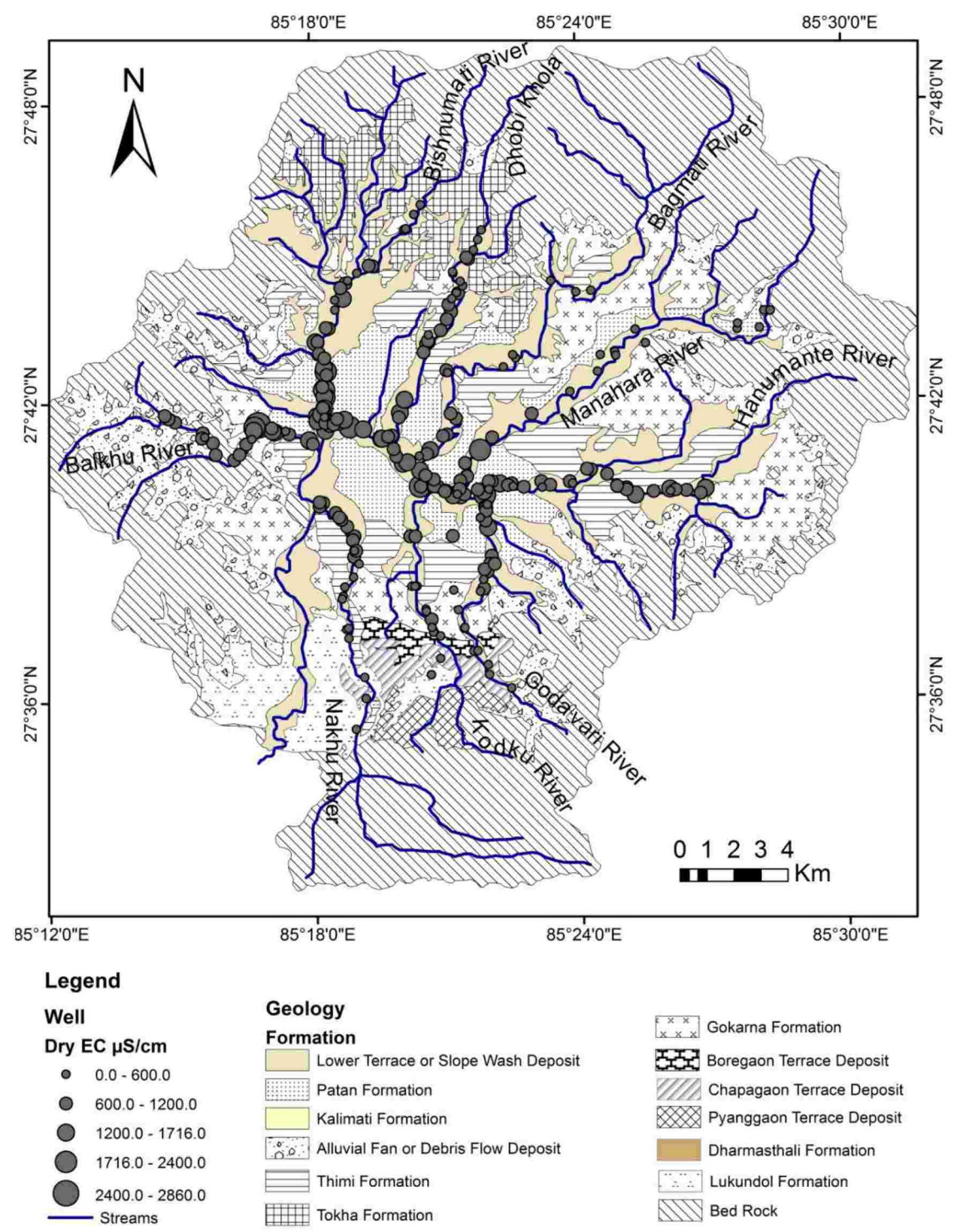

Fig. 6: Variation of EC in dry season

limit of NDWQS $(1500 \mu \mathrm{S} / \mathrm{cm})$. The EC values in the samples from the downstream of other seven tributaries exceeds limit of NDWQS and indicate unsuitability for drinking purpose.

\section{Dissolve Oxygen (DO)}

Dissolved oxygen refers to the level of free, noncompound oxygen present in water. It is an important parameter in assessing water quality because of its influence on the organism living within a body of water. DO variation depends on temperature, pressure and salinity of water (Fundamentals of Envirnmental Measurements, 2015). The average DO varied from 1.46 to $2.46 \mathrm{mg} / \mathrm{L}$ in dry season and increased to 1.67 and
$2.53 \mathrm{mg} / \mathrm{L}$ in wet season. Most of the wells have higher DO during wet season. The highest DO was recorded in the samples from the upstream section of all rivers, and DO decreased in samples lying towards core areas of the Kathmandu Valley. In the study area, DO increased as temperature and EC decreased.

Comparing nine rivers, minimum value was obtained from the downstream of the Kodku Khola $(0.09 \mathrm{mg} / \mathrm{L})$ and maximum value was found in the sample fromthe upstream of the Dhobi Khola $(6.06 \mathrm{mg} / \mathrm{L})$ in dry season (Fig. 8). In wet season, minimum $(0.26 \mathrm{mg} / \mathrm{L})$ and maximum $(8.55 \mathrm{mg} / \mathrm{L})$ values of DO was recorded in samples from the downstream and the upstream segments of the Bagmati River (Fig. 9). 


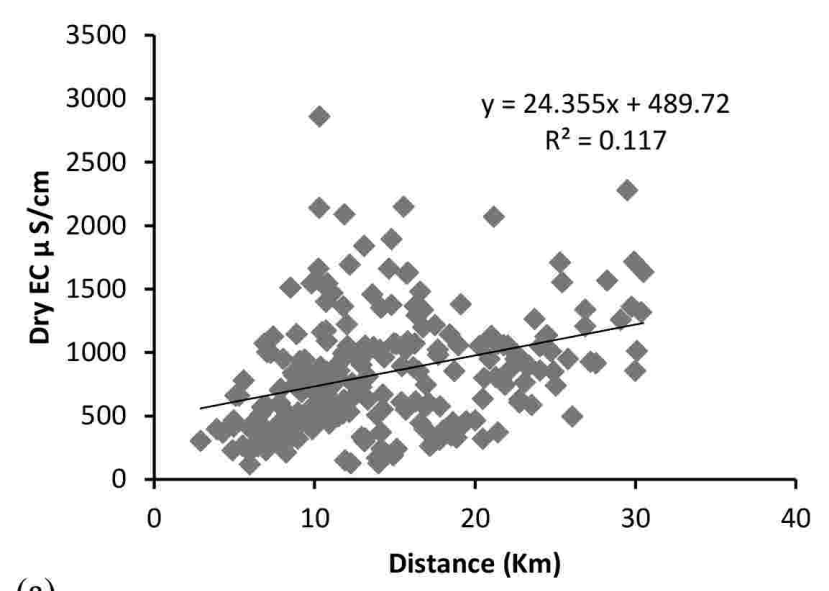

(a)

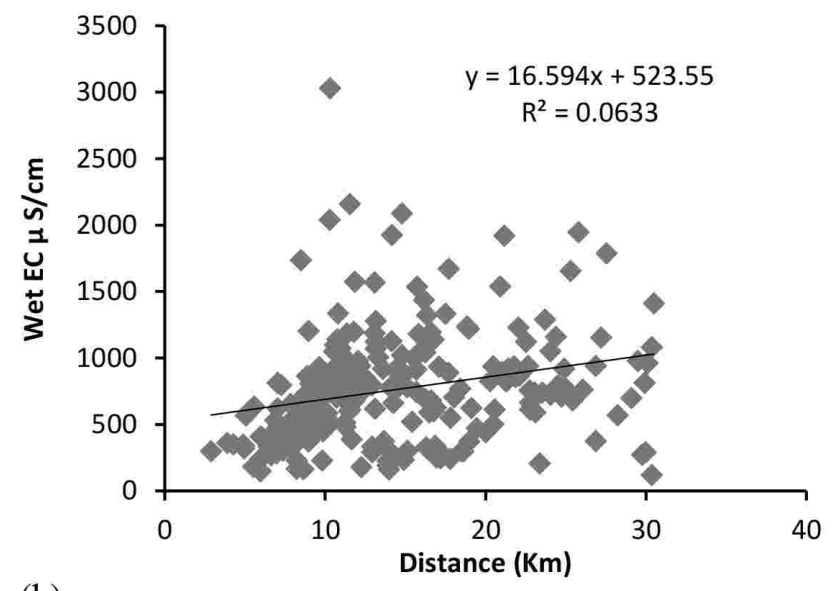

(b)

Fig. 7: EC verses downstream distance of well location from the origin of each river in a) dry season and b) wet season

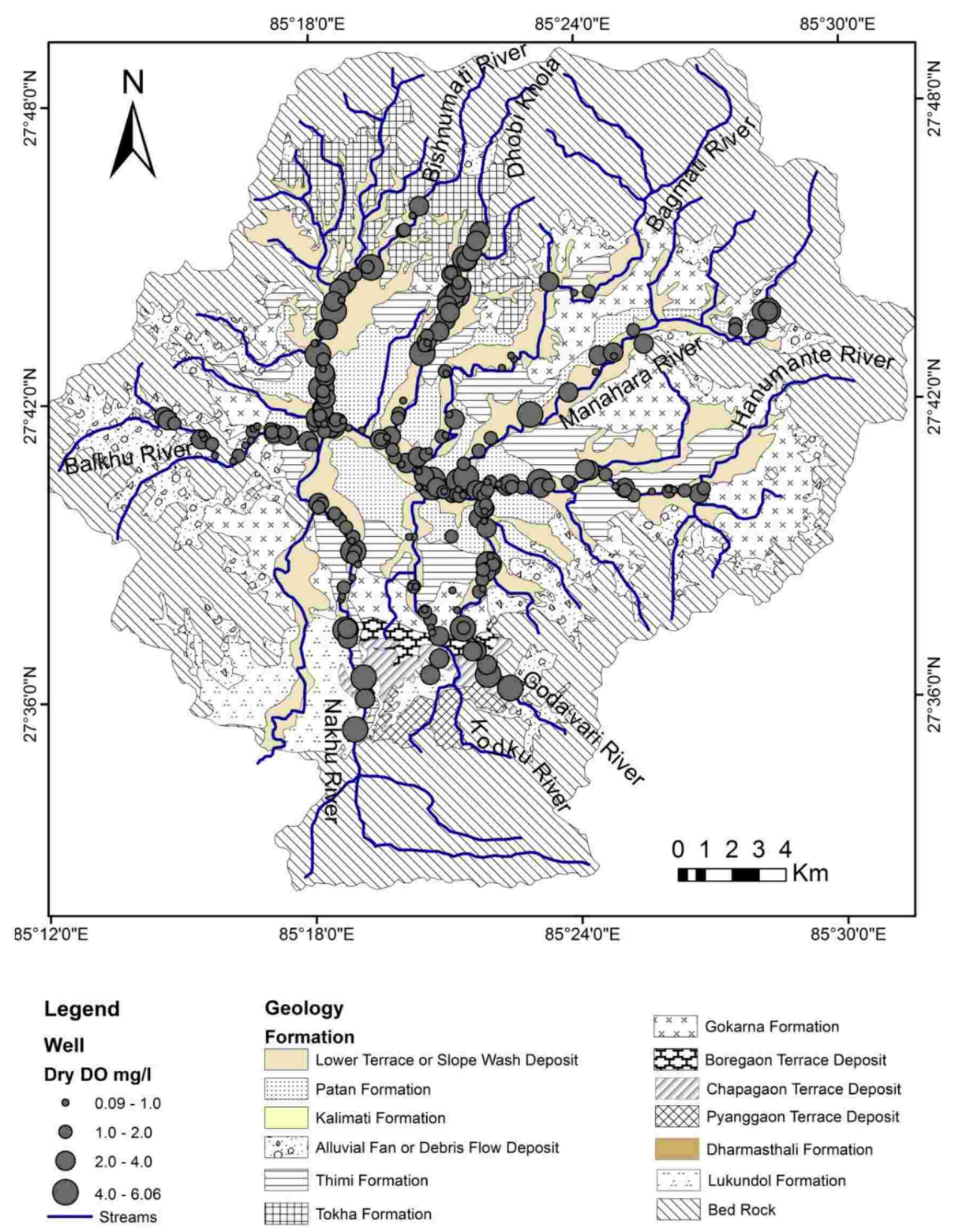

Fig. 8: DO variation in dry season 


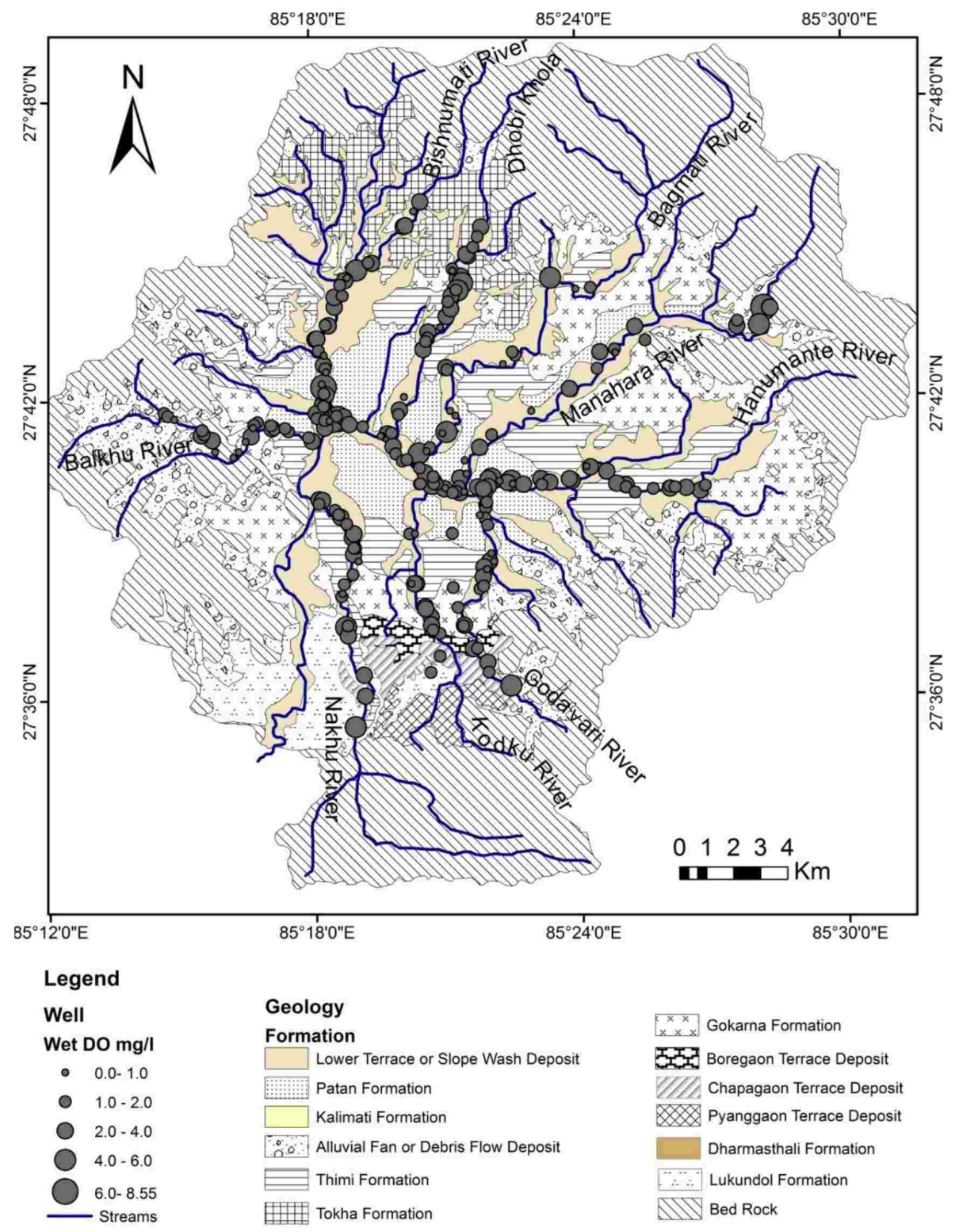

Fig. 9: DO variation in wet season

\section{Relation between physical parameter of water and distance from river channel to well location}

In present investigation, wells which were located within $100 \mathrm{~m}$ from major rivers of the Kathmandu valley were used. Wells were divided into 4 categories as 0-30 m, 30-60 m, 60-90 $\mathrm{m}$ and above $90 \mathrm{~m}$ from river channel. Variation of EC, DO, temperature and $\mathrm{pH}$ related with the distance were studied in this part.

EC was found highest in those wells which were located within $30 \mathrm{~m}$ from river channels having average value 878.2 $\mu \mathrm{S} / \mathrm{cm}$. EC values decreased to $858.1 \mu \mathrm{S} / \mathrm{cm}, 727.2 \mu \mathrm{S} / \mathrm{cm}$ and $378.1 \mu \mathrm{S} / \mathrm{cm}$ as the distance from river channel increased to $30-60 \mathrm{~m}, 60-90 \mathrm{~m}$ and above $90 \mathrm{~m}$, respectively in dry season (Table 4). But within $30 \mathrm{~m}$ distance also, there was wide range of values with minimum of $231 \mu \mathrm{S} / \mathrm{cm}$ and maximum 2860 $\mu \mathrm{S} / \mathrm{cm}$. The minimum value was recorded from upstream section whereas maximum value was noted from downstream section. Average EC value was decreased to $765.6 \mu \mathrm{S} / \mathrm{cm}$ in wet season which was located within $30 \mathrm{~m}$ but other wells located between 30-60m, 60-90 m and above $90 \mathrm{~m}$ have higher EC as compared to dry season. The average $\mathrm{pH}$ and temperature were similar in wet and dry season in all 4 categorical ranges of distances. There was no any difference observed in relation to distance from river channel. But in the case of DO, the lowest average value $(1.9 \mathrm{mg} / \mathrm{L})$ was found within $30 \mathrm{~m}$ and increased to 2.1 $\mathrm{m} / \mathrm{L}$ as the distance from river increased. The combined information on EC and DO suggests two possibility: (1) recharge from the polluted river water to the groundwater and contaminated groundwater (Gautam et al., 2013) and (2) leachate from solid waste, sewer and industrial disposal near the river banks contaminated the groundwater of shallow wells. 
Table 4: Physical parameters and distance from river channel

\begin{tabular}{|c|c|c|c|c|c|c|c|c|c|}
\hline \multicolumn{2}{|c|}{ Parameters } & \multicolumn{8}{|c|}{ Distance from river channel } \\
\hline & & \multicolumn{2}{|c|}{ 0-30 } & \multicolumn{2}{|c|}{$30-60$} & \multicolumn{2}{|c|}{$60-90$} & \multicolumn{2}{|c|}{$>90$} \\
\hline & & Dry & Wet & Dry & Wet & Dry & Wet & Dry & Wet \\
\hline \multirow[t]{3}{*}{$\mathrm{EC}$} & Min & 231 & 121.7 & 126.8 & 160.5 & 169.9 & 190 & 119.8 & 148.5 \\
\hline & Max & 2860 & 2090 & 2090 & 2158 & 1637 & 1413 & 1092 & 1142 \\
\hline & Average & 878.2 & 765.6 & 858.1 & 817.0 & 727.2 & 646.0 & 378.1 & 475.0 \\
\hline \multirow[t]{3}{*}{$\mathrm{pH}$} & Min & 6.46 & 5.33 & 6.35 & 6.73 & 5.67 & 5.92 & 5.96 & 6.51 \\
\hline & Max & 8.5 & 8.3 & 7.73 & 7.85 & 8.03 & 7.87 & 7.23 & 7.82 \\
\hline & Average & 7.1 & 7.3 & 7.1 & 7.3 & 7.0 & 7.2 & 6.5 & 7.2 \\
\hline \multirow[t]{3}{*}{ DO } & Min & 0.09 & 0.19 & 0.19 & 0.36 & 0.11 & 0.59 & 0.31 & 1.02 \\
\hline & Max & 5.93 & 8.55 & 6.06 & 4.81 & 4.75 & 3.88 & 4.61 & 6.36 \\
\hline & Average & 1.9 & 2.2 & 2.1 & 2.0 & 2.0 & 1.9 & 2.1 & 2.8 \\
\hline \multirow[t]{3}{*}{ Temp. } & Min & 15.3 & 19.6 & 15.5 & 21 & 15.4 & 21 & 18.8 & 20.2 \\
\hline & Max & 21.6 & 25.8 & 23.4 & 25.8 & 24 & 27.6 & 16 & 24.1 \\
\hline & Average & 19.0 & 23.3 & 19.3 & 23.5 & 18.9 & 23.4 & 19.7 & 23.0 \\
\hline
\end{tabular}

\section{CONCLUSIONS}

All physical parameter and water level depth was spatially and seasonally variable. Water level depth was the least in the wells of the Nakhu Khola corridor in both dry and wet season whereas the highest values were recorded in the wells of the Dhobi Khola and the Kodku Khola corridors in dry and wet seasons, respectively. Average temperature and $\mathrm{pH}$ value ranged from 17.67 to $19.83 \mathrm{oC}$ and 6.16 to 7.33 in dry season which increased to the range from 22.8 to $23.6^{\circ} \mathrm{C}$ and 7.19 to 7.41 in wet season, respectively. Similarly, DO average value was obtained within 1.46 to $2.46 \mathrm{mg} / \mathrm{L}$ in dry season and was found to increase to 1.67 and $2.53 \mathrm{mg} / \mathrm{L}$ in wet season. But in the case of EC, it decreased from dry season $(614.2$ and $1123.9 \mu \mathrm{S} / \mathrm{cm})$ to wet season $(613.0$ and $916.1 \mu \mathrm{S} / \mathrm{cm})$ indicating dilution in ionic concentration due to rainfall infiltration. EC and DO show inverse relation and both indicate that wells located at the core or urbanized area have been more contaminated than those of the outer regions due to greater anthropogenic activities in the core area.

Average EC of wells located within $30 \mathrm{~m}$ from the river channel has the highest value as compared with other wells. These wells also showed lower DO indicating higher possibility of contamination near river banks due to leachate of solid waste, industrial and sewer disposal. There is also possibility of recharge from the polluted river water to shallow groundwater which was close to river bank (approx 0-60 m) through bank infiltration.

\section{ACKNOWLEDGMENTS}

Authors are thankful to the Central Department of geology for providing test kits and suitable environment for research. Authors are also thankful to Prof. Dr. Suresh Das Shrestha for providing valuable suggestion and comments during this research work and Ms. Mamata Sayami for supporting preparation of maps in GIS.

\section{REFERENCES}

Aytekin, H. and Bayraktaroglu, N., 2014, An investigation on the quality of natural spring waters in Zonguldak Provinance (Turkey) Academic Library Collections in Korea. J. Korean Libr. Inf. Sci. Soc. v. 45, pp. 277-308. https://doi.org/10.16981/kliss.45.4.201412.277

Diwakar, J., Yami, K.D., and Prasai, T., 2010, Assessment of drinking water of Bhaktapur Municipality area in premonsoon season. Sci. World, v. 6, pp. 94-98.

Dhital, M.R., 2015, Geology of the Nepal Himalaya: Regional perspective of the classical collided orogen. Switzerland: Springer International Publishing, pp. 448-453

Fundamentals of envirnmental measurements, 2015. Dissolved oxygen-environmental measurement systems. Fundam. Envirnmental Meas.

Gautam, D. and Prajapati, R.N., 2014, Drawdown and dynamics of groundwater table in Kathmandu Valley, Nepal. Open Hydrol. J., v. 8, pp. 17-26. https://doi.org/ $10.2174 / 1874378101408010017$

Gautam, R., Shrestha, J.K., Kumar, G., and Shrestha, C., 2013, Assessment of river water intrusion at the periphery of Bagmati River in Kathmandu Valley. Nepal J. Sci. Technol., v. 14, pp.137-146.

Ghimire, G., Adhikari, B., and Pradhan, M., 2013, Bacteriological analysis of water of Kathmandu Valley. MJSBH, v. 12, pp. 19-22 
Khadka, M.S., 1993, The groundwater quality situation in alluvial aquifer of the Kathmandu Valley, Nepal. AGSO Journal of Australian Geology and Geophysics, v. 14, pp. 207-211

Ngabirano, H., Byamugisha, D., and Ntambi, E., 2016, Effects of seasonal variations in physical parameters on quality of gravity flow water in Kyanamira Sub-County, Kabale District, Uganda. J. Water Resour. Prot., v. 8, pp.1297-1309. https://doi.org/10.4236/jwarp.2016.813099

Oyem, H.H., Oyem, I.M., and Ezeweali, D., 2014, Temperature, $\mathrm{pH}$, electrical conductivity, total dissolved solids and chemical oxygen demand of groundwater in BojiBojiAgbor/Owa Area and Immediate suburbs. Environmental Sciences. Res. J. Environ. Sci., v. 8, pp. 444-450. https://doi.org/10.3923/ryes.2014.444.450

Pandey, V.P., Chapagain, S.K., and Kazama, F., 2010, Evaluation of groundwater environment of Kathmandu valley. Environ. Earth Sci., v. 60, pp. 1329-1342.

Pandey, V.P., Shrestha, S., and Kazama, F., 2012. Groundwater in the Kathmandu Valley: Development dynamics , consequences and prospects for sustainable management. Eur. Water, v. 37, pp. 3-14.

Pant, B.R., 2011. Ground water quality in the Kathmandu valley of Nepal. Environ. Monit. Assess., v. 178, pp. 477-485. https://doi.org/10.1007/s 10661-010-1706-y

Pathak, D.R. and Hiratsuka, A., 2010, An investigation of nitrate and iron concentration and their relationship in shallow groundwater system of Kathmandu. Desalination and Water Treatment, v. 19, pp.191-197.

Prasai, T., Lekhak, B., Joshi, D.R., and Baral, M.P., 2010, Microbiological analysis of drinking water of Kathmandu Valley. Sci. World, v. 5, pp. 112-114. https://doi.org/10.3126/sw.v5i5.2667

Ramamohan, H. and Sudhakar, I., 2014, Evaluation of ground water quality for the pre and post-monsoon variations in physico-chemical characteristics of North East Coast of Srikakulam District, A.P., India, v. 3, pp. 124-131.

Sakai, T., Gajurel, A.P., Tabata, H., Ooi, N., Takaawa, T., Kitagawa, H., and Upreti, B.N., 2008, Revised lithostrtigraphy of fluvio-lacustrine sediments comprising northern Kathmandu Basin in Central Nepal. Journal of Nepal Geological Society, v. 37, pp. 25-44.

Shrestha,O.M., Koirala, A., Hanisch, Jorg., Busch, K., Kerntke, M., and Jager, S., 1999, A Geo-environmental map for the sustainable development of the Kathmandu Valley, Nepal. GeoJournal, v. 49, pp. 165-172

Shrestha, S. and Shah, S., 2014, Final report on shallow aquifer mapping of Kathmandu Valley. submitted to Groundwater Resources Development Board, Babarmahal, Kathmandu, $49 \mathrm{p}$.

Stocklin, J., 1980, Geology of Nepal and its regional frame. Journal of Geological Society of London, v. 137, pp. 1-34

Warner, N.R., Levy, J., Harpp, K., and Farruggia, F., 2008, Drinking water quality in Nepal's Kathmandu Valley: A survey and assessment of selected controlling site characteristics. Hydrogeol. J., v. 16, pp. 321-334. https://doi.org/10.1007/s 10040-007-0238-1

WHO Nepal, 2005. National drinking water quality standards, $22 p$ http://mowss.gov.np/article/34/national-drinking-waterquality-standards-2062.html,

Yoshida, M. and Igarashi, Y., 1984, Neogene to quaternary lacuastrine sediments in the Kathmandu Valley, Nepal. Jour. Nepal Geological Society, Special Issue, v. 4, pp. 73-100. 